\title{
Free College and the Problem of College Readiness
}

\author{
Jackson Toby
}

President Biden has proposed free community college and substantial subsidies at public four-year colleges. If he means to require the beneficiaries to demonstrate that they have enough aptitude to graduate if they choose to study, the idea would be in the tradition of Thomas Jefferson's 1817 plan for selecting students of "genius" for scholarship admission to the University of Virginia. But President Biden has never mentioned college readiness to accompany financial aid for college students. If he means to make college available for free without vetting student beneficiaries for college readiness, he is underestimating the educational problem underprepared students would impose.

Adolescents develop college readiness partly by early schooling. In addition to reading, writing, and arithmetic, they learn to be "culturally literate," the term coined by University of Virginia Professor E. D. Hirsch to describe what people need to know in order to understand the world in which they will live. For instance, they learn that "geography" refers to oceans and distant countries and "insect" refers to mosquitoes and flies that they see around them. The word "library" is not simply a building containing objects called "books"; a culturally literate person knows that the books contain information on a wide variety of subjects and that the books are carefully stored according to their content so they can be found and perhaps borrowed for further study by interested patrons. Crucially, the culturally literate adolescent learns that answers to many questions are available in library books.

Cultural literacy develops not only in school but in the family and the neighborhood. For instance, in a family a child may learn that a "meal" is not simply getting fed but an activity that takes place around a table at a prearranged time with particular people who are expected to be present. A person also gets culturally literate from learning why people go to stores and jobs and libraries.

Jackson Toby is professor emeritus of sociology at Rutgers University, where he was director of the Institute for Criminological Research; jtoby@scarletmail.rutgers.edu. His most recent book is The Lowering of Higher Education in America (Praeger 2009). Toby last appeared in AQ in the summer of 2021 with "Students Are Literate but They Do Not Read." 
The people rushing to catch commuter trains or buses in the early morning are not heading for parties. They want to get to work on time.

Cultural literacy is not usually considered among the specific requisites necessary for college readiness. But without considerable cultural literacy, adolescents would not be curious enough about the world they live in and about the thoughts of previous generations to learn more about these unknowns at college. They don't need to have narrowed their interests to a specific field of knowledge, but they do need to recognize that the main purpose of attending college is to find a field in which to study seriously. As a mental experiment showing why cultural literacy is necessary, consider why the fictional Tarzan would not be ready for college. Tarzan of the Apes, a novel published in 1912, told the story of an infant born to English parents, Viscount and Lady Greystoke, who was adopted and raised by a nurturant ape mother in an African jungle after the death of his parents. This implausible novel became very popular, making its author, Edgar Rice Burroughs, rich and famous. Burroughs wrote twenty-four volumes of Tarzan sequels; and Hollywood studios made at least a dozen Tarzan movies and a television series about him. Burroughs did not imagine Tarzan attending college. Had he done so, Tarzan's fans would probably have believed that Tarzan's natural intelligence was evident enough to get him admitted to college without graduating from high school, taking college prep courses, and getting at least an acceptable score on the Scholastic Aptitude Test. More problematic would be why he would be interested in studying any subject that the college offered its students. While he was learning to swing from trees and successfully fight jungle animals-and perhaps enjoying learning those necessary survival skills, he was not becoming culturally literate. Nor was he learning what thousands of words mean, how to spell them, how to organize them according to grammatical rules, and how to use periods, commas, and other punctuation marks. He needed such knowledge in order to understand what professors say in classroom lectures, how to complete reading assignments, and how to write research papers. Equally important, he would have to learn the difference between the professor, who knows more about the subject and ought to be listened to, and the students who know less about it and ought to listen.

Would Tarzan like college? Probably not, as he was not culturally literate. He may have learned several hundred words of English, which would enable him to talk with the other students. But what would he talk about? He would 
spend a great deal of time at the Recreation Center where his skills at rope climbing, swimming, and other sports would gain him admirers. But it would soon become clear to him that none of the courses in which he might enroll would be about anything he wanted to learn.

A prospective college student raised in the African jungle does not occur except in fiction. However, children are born to human parents who do not give them much more opportunity to become culturally literate than Tarzan had, sometimes because of death or disability of one or both of his parents, sometimes because of parental mental illness, alcoholism, or drug abuse. In what sociologists call our "isolated conjugal family" system, neither fathers nor mothers are easily replaced. Children in some households do not hold conversations with adults during meals, where they might have opportunities to expand their vocabularies with words they need to know in order to understand what is going on in a college class. They feed themselves from the refrigerator or buy something in a diner or fast-food restaurant. They have deprived childhoods, but the deprivation is not primarily due to poverty. The problem is the unintended neglect that some children experience in a small conjugal family where a crucial adult caregiver is missing. Children cannot bring themselves up. They need an adult to expect them to be ready for school every day and, after school, to ask them whether they have homework to complete; such experiences can teach them to discipline themselves to fulfill obligations on time whether they want to or not.

All colleges have remedial programs for admitted students with poor academic skills. But most students assigned to remedial courses now are students who are culturally literate enough to be curious about some discipline they could find at college. Only students who are aware that they are missing something in their college preparation are motivated to put in the effort required for remediation.

Teenagers who start life as intelligent infants but did not become culturally literate gradually are unlikely to catch up by taking even very good remedial courses. They would waste their time and somebody's money if they go to college without better academic readiness. Research shows that the more remedial courses such students have to take, the higher their rate of quitting college. Some relaxation of strict academic requirements occurs at all colleges, appropriately, to make them more interesting places, but relaxation is not synonymous with abandoning their reason for existence. Whatever else colleges 
are, they should be primarily educational institutions. If college applicants' SAT scores, or even their classroom GPAs, reveal that they have little chance of graduating from college, will President Biden be willing to screen them out of a free college program? Up until now, the president has been silent about college readiness. 